ISSN 0258-7122

Bangladesh J. Agril. Res. 33(3) : 503-513, September 2008

\title{
DETERMINATION OF RESIDUE OF DIAZINON AND CARBOSULFAN IN BRINJAL AND QUINALPHOS IN YARD LONG BEAN UNDER SUPERVISED FIELD TRIAL
}

\author{
K.H. KABIR ${ }^{1}$, M.A. RAHMAN ${ }^{2}$, M.S. AHMED ${ }^{3}$ \\ M.D.H. PRODHAN ${ }^{4}$ AND M.W. AKON ${ }^{5}$
}

\begin{abstract}
The present study was undertaken to detect and quantify the left over residue of Diazinon and Carbosulfan in brinjal and Quinalphos in yard long bean and comparison between the detected residue level with maximum residue level (MRL) set by FAO (1970). Three supervised field trials (two for brinjal and one for yard long bean) were carried out sprayed with the field dose $(1.5 \mathrm{ml} / \mathrm{L}$ of water) of Diazinon, Carbosulfan, and Quinaiphos. Samples were collected daily after spraying till residue were found. In case of Diazinon, left over residue was found upto 6 days after spray (DAS), and upto 3 DAS, the level of residue was above the MRL. Carbosulfan residue was detected till 7 DAS and the detected quantity of residue was above MRL upto 3 DAS. Left over residue of Quinalphos in yard long bean sample was detected upto 6 DAS and upto 4 DAS the level of residue was above the MRL.
\end{abstract}

Key Words: Residue, Diazinon, Carbosulfan, Quinalphos. brinjal, yard long bean.

\section{Introduction}

In Bangladesh, the food production has more than doubled since 1971, but the food security still remains a major development issue for its huge population (Weinberger and Genova, 2005). As the process of agricufural production is supported by the increasing use of agrochemicals and multiple cropping, the Government of Bangladesh has called for departure from rice-led production to a more diversified production base that includes several non-rice crops (Hoque, 2000). Diversification in vegetable crops and increasing commercialization can support the development of the agriculture sector in several ways. But, in case of vegetables, data show the output growth in Bangladesh mainly through area expansion, without much improvement in yield. One potential drawback associated with a shift toward more intensive vegetable production is the reliance of most vegetable producers on heavy application of pesticide (Hossain el al., 2000). Among the vegetables grown in Bangladesh, brinjal and yard long bean are high valued and popular crop. It has been reported that these vegetables are

\footnotetext{
${ }^{1}$ Principal Scientific Officer, ${ }^{2 \& 3}$ Senior Scientific Officer, ${ }^{4 \& 5}$ Scientific Officer, Pesticide Research and Environmental Toxicology Section, Division of Entomology, BARI, Joydebpur, Gazipur-1701, Bangladesh.
} 
severely attacked by insect pests and farmers sprayed insecticides quite frequently even every day (Anon., 2000). The development of agriculture, the improvement of the food production technology and mainly the demands of the new markets for better products both in quality and quantity have been made among others with intensive uses of pesticides for ensuring productivity (Trevisan et al., 2004). Pesticide being toxic can become a potential hazard to the manufacturers, the users, the public at large and the environment. Pesticide can produce negative impacts, both socially and economically (Antle and Pingali, 1994). Extensive use of pesticides has resulted in contamination of vital supplies, air, water, and food, the risk to humans may be short term as well as long term depending on the persistence of the pesticide and the exposure period. Pesticide residue in food has become a consumers' safety issue and the consumers have the right to know how much pesticide get incorporated in the food they eat. The detection, identification, and quantification of pesticide in the food are becoming the public interest. But very little references are available on the presence of pesticides in vegetables in Bangladesh (Khatoon et al., 2004). Therefore, this study was undertaken to assess the quantity and degradation rate of left over residue of three frequently used pesticides in brinjal and yard long bean.

\section{Materials and Method}

The standard for the pesticides Diazinon, Carbosulfan, and Quinalphos were obtained from Sigma-Aldrich Laborchemikalien, Gmbh P.O. Box-100262 D30918, Seelze, Germany via Bangladesh Scientific Pvt. ltd., Dhaka, Bangladesh. Standards of all the pesticides contained $>99.6 \%$ purity. Vegetable samples (brinjal and yard long bean) were collected from three different supervised field trials at each day after spray (DAS) (where 0 DAS means sample were collected after 2 hours of spraying), which were sprayed with Quinalphos, Diazinon, and Carbosulfan @1.5 ml/L of water. The formulated products of those were Kinalux 20 EC, Sunsulfan 20 EC, and Rison 60 EC, respectively. The purity of all formulated insecticides was tested in this laboratory and found to be $100 \%$.

\section{Extraction and separation of Quinaiphos and Carbosulfan}

Field collected samples ( $\geq 250 \mathrm{~g}$ ) (brinjal for Quinalphos and yard long bean for Carbosulfan) were grounded thoroughly with the meat grinder (Handmixer M122, Bamix, Switzerland). A sub sample of $25 \mathrm{~g}$ was taken into a wide mouth jar then $100 \mathrm{ml}$ of hexane was added to it. Sodium sulphate $\left(\mathrm{Na}_{2} \mathrm{SO}_{4}\right)$ was also added (as required) with sample until water was removed from the sample. The mixture was then macerated with high-speed homogenizer (Ultraturax, IKA T18 basic, 
Germany) for 2 minutes. The homogenized material was then poured into $250 \mathrm{ml}$ conical flask and placed into shaker (Orbital Shaking Incubator, Rexmed, Sweden) for 12 hrs continuous shaking. After shaking, the slurry was filtered through a Buchner funnel with suction. The flask and filter cakes were rinsed with $25 \mathrm{ml}$ of hexane each. The filtrate was then transferred into $250 \mathrm{ml}$ round bottom flask and was dried to 3-5 $\mathrm{ml}$ by evaporation using a rotary vacuum evaporator (Laborota-4001, Heidolph, Germany). The concentrated filtrate was then transferred into $500 \mathrm{ml}$ separatory funnel making $5 \mathrm{ml}$ in volume. Around $20 \mathrm{ml}$ methane was added with $5 \mathrm{ml}$ filtrate and shaked vigorously with the shaker (Orbital Shaking Incubator, Rexmed, Sweden) for 3-5 minutes. After shaking, the separatory funnel was set on stand and kept undisturbed for 3-5 minutes. Then the clear part of the solution from the bottom of the separatory funnel was collected in vial which was then centrifuged at $1200 \mathrm{rpm}$ for 5 minutes (Laboratory Centrifuges, Sigma-3K30, Germany). After centrifuge, supernatant was collected for injection.

\section{Extraction of Diazinon}

Field collected samples (250g) were chopped and $20 \mathrm{~g}$ sub sample was taken for extraction with super critical fluid extraction system (Super 201, Jasco, Japan) using pressure of $\mathrm{CO}_{2} 31 \mathrm{bar}$, temperature $40^{\circ} \mathrm{C}$, n-Hexane $(10 \mathrm{ml})$ as solvent and $\mathrm{n}$-Hexane $100 \mathrm{ml}$ as modifier. The extracted materials were collected in vial and mixed with n-Hexane making the volume to $5 \mathrm{ml}$. The vial was then centrifuged at $1200 \mathrm{rpm}$ (Laboratory Centrifuges, Sigma-3K30, Germany) for 5 minutes. And then, supernatant was collected for injection.

\section{Detection and quantification of pesticide residue in samples}

The concentrated extracts were subjected to analysis by GC-MS QP2010 (Shimadzu). For Carbosulfan El (Electron Ionization) mode and for Quinalphos and Diazinon NCI (Negative Chemical Ionization) mode were used. The capillary column used in both cases was AT-I, length 30m, ID $0.25 \mathrm{~mm}$ and film thickness $0.25 \mu \mathrm{m}$. Helium was used as carrier and make up gas in both modes. For NCI, Methane was used as reagent gas. Flow rate of carrier gas in the column was $1.69 \mathrm{ml} / \mathrm{min}$ in case of Diazinon, $1.50 \mathrm{ml} / \mathrm{mm}$ for Carbosulfan and $1.88 \mathrm{ml} / \mathrm{min}$ for Quinaiphos. For NCI mode reagent gas was set with 0.1 Mpa pressure.

Prior to the injection of the sample extract, standard solutions of different concentrations of each pesticide group were prepared and injected with appropriate instrument parameters. The samples were calibrated (retention time, peak area, etc.) against three to four pointed calibration curve of standard solution of concerned pesticide. Each peak was characterized by its retention 
time. Sample results were expressed in ppm automatically by the GC software which represents the concentration of the final injected volume. From this value, the actual amount of pesticide residue present in the sample was determined by using the following formula.

Residue in sample (ppm)

Conc. obtained in injected volume $(\mathrm{ppm}) \times$ Quantity of final volume $(\mathrm{L})$

Amount of sample taken $(\mathrm{kg})$

The instrument parameters for detecting different pesticides are as follows.

\section{Diazinon}

[GC-20 10]:

Column Oven Temp. $\quad: 600{ }^{\circ} \mathrm{C}$

Injection Temp.

Injection Mode

Flow Control Mode

Oven Temp.

Rate Temperature $\left({ }^{\circ} \mathrm{C}\right)$

$\begin{array}{ll}- & 60.0 \\ 2.00 & 180.0\end{array}$

$2.00-180.0$

1.00

250.0

\section{: $250.00{ }^{\circ} \mathrm{C}$}

: Splitless

: Linear Velocity

: Program

Hold Time (mm)

1.00

2.00

2.00
[GCMS-QP2O 10]:

IonSourceTemp

Solvent Cut Time

Ionization Mode : NCI

Start Time $\quad: 4.00 \mathrm{~mm}$

End Time $\quad: 15.50 \mathrm{~mm}$

ACQ Mode : : SIM

Interval $\quad: 0.20 \mathrm{sec}$

Ch1-m/z $\quad: 169.0$

\section{Carbosulfan}

[GC-2010]:

Column Oven Temp. $\quad: 500^{\circ} \mathrm{C}$

Injection Temp. $\quad: 250.00^{\circ} \mathrm{C}$

Injection Mode

Oven Temp. Program

Rate Temperature $\left({ }^{\circ} \mathrm{C}\right)$

$\begin{array}{ll}- & 50.0 \\ 20.0 & 240.0\end{array}$

\section{: Splitless}

Hold Time (mm)

1.00

5.00
[GCMS-QP2O 10]:

lonSourceTemp $: 200.00^{\circ} \mathrm{C}$

Interface Temp. $\quad: 280.00^{\circ} \mathrm{C}$

Solvent Cut Time $\quad: 5.00 \mathrm{~min}$

Ionization mode : : EI

Start Time $\quad: 5.00 \mathrm{~mm}$

End Time $\quad: 18.00 \mathrm{~mm}$

ACQ Mode : : SIM

Chi $-\mathrm{m} / \mathrm{z} \quad: 118.00$

Ch2-M/Z : 160.00

\section{Quinaiphos}

[GC-20 10]:

Column Oven Temp. $\quad: 600^{\circ} \mathrm{C}$

Injection Temp. $\quad: 250.00^{\circ} \mathrm{C}$

Injection Mode : Splitless

Flow Control Mode $\quad$ : Linear Velocity

Oven Temp. Program

Rate Temperature $\left({ }^{\circ} \mathrm{C}\right)$

$\begin{array}{ll}- & 60.0\end{array}$

Hold Time (mm)

1.00

20.0

240.0

5.00

[GCMS-QP2O 10]:

\section{IonSourceTemp}

: $200.00^{\circ} \mathrm{C}$

Interface Temp.

$280.00^{\circ} \mathrm{C}$

Solvent Cut Time $\quad 4.00 \mathrm{~mm}$

Ionization Mode

$\mathrm{NCI}$

Start Time

$4.00 \mathrm{~mm}$

$15.00 \mathrm{~mm}$

SIM

ACQ Mode

Chl-m/z

169.00

Ch2-m/z 


\section{Results and Discussion \\ Diazinon (Rison 60 EC)}

The concentrated extracts of brinjal samples of different days after spray (DAS) were subjected to analysis by GC-MS QP2OIO with the pre-set parameters. Fig Fig. 1 show the chromatograms of the injected extracts of brinjal sample containing Diazinon at different DAS.

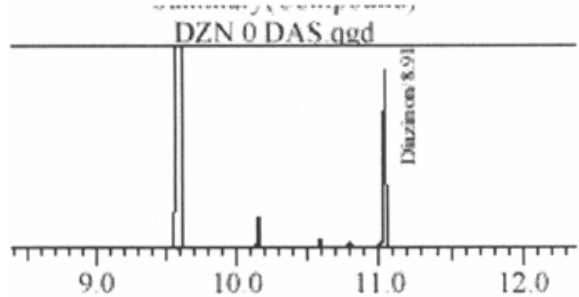

Fig. 1. Chromatogram of Diazinon obtained from brinjal extract after 0 DAS.

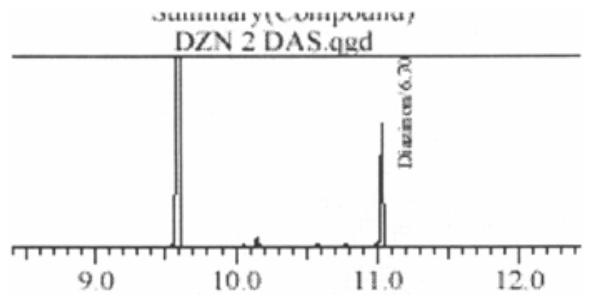

Fig. 3. Chromatogram of Diazinon obtained from brinjal extract after 2 DAS.

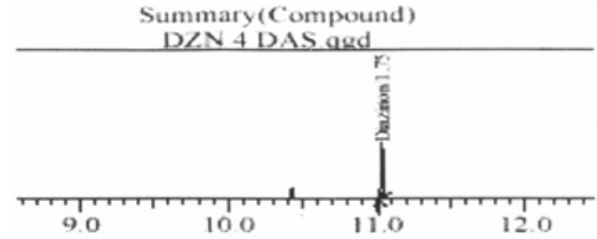

Fig. 5. Chromatogram of Diazinon obtained from brinjal extract after 4 DAS.

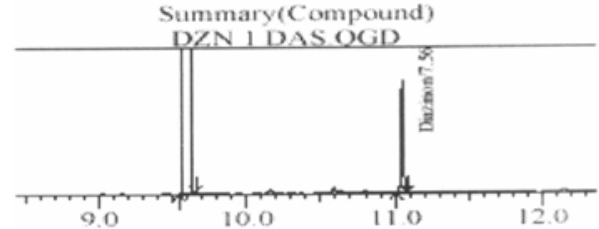

Fig. 2. Chromatogram of Diazinon obtained from brinjal extract after I DAS. Summary(Compound)

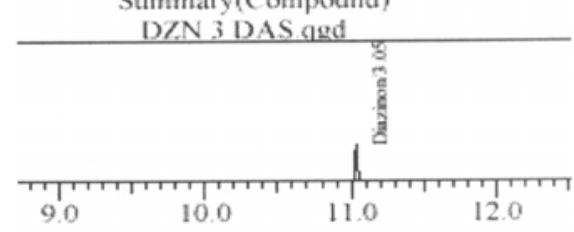

Fig. 4. Chromatogram of Diazinon obtained from brinjal extract after 3 DAS.

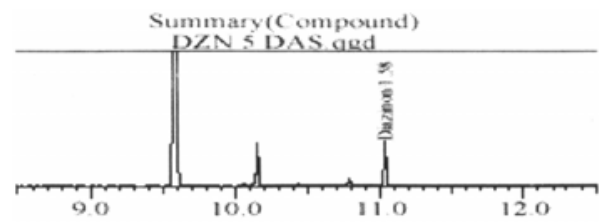

Fig. 6. Chromatogram of Diazinon obtained from brinjal extract after 5 DAS.

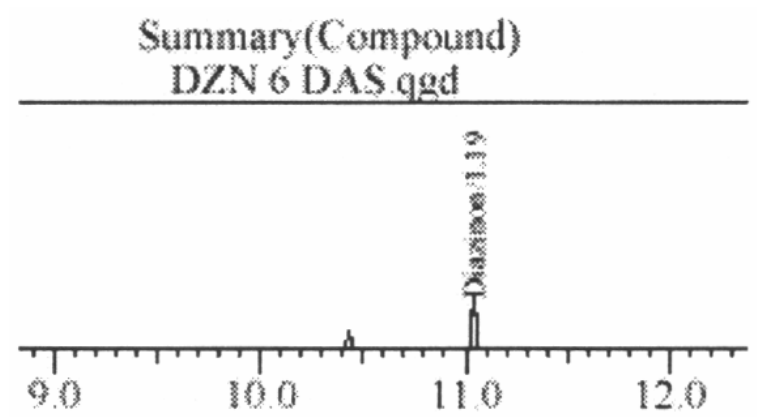

Fig. 7. Chromatogram of Diazinon obtained from brinjal extract after 6 DAS. 
The results of the analysis of Diazinon residue in brinjal sample are summarized in the Table 1.

Table 1. Quantity of residue of Diazinon (Rison 60EC) estimated from brinjal at different days after Spray (DAS).

\begin{tabular}{c|c|c|c|c|c}
\hline $\begin{array}{c}\text { Days after } \\
\text { spraying }\end{array}$ & $\begin{array}{c}\text { Sample } \\
\text { wt }(\mathrm{g})\end{array}$ & $\begin{array}{c}\text { Total volume } \\
\text { prepared }(\mathrm{ml})\end{array}$ & $\begin{array}{c}\text { Injected } \\
\text { volume } \\
(\mu \mathrm{l})\end{array}$ & $\begin{array}{c}\text { Conc. obtained in } \\
\text { final volume } \\
(\mathrm{ppm})\end{array}$ & $\begin{array}{c}\text { Residue of } \\
\text { Rison left } \\
(\mathrm{ppm})\end{array}$ \\
\hline 0 & 20 & 5 & 2 & 8.914 & 2.228 \\
1 & 20 & 5 & 2 & 7.559 & 1.889 \\
2 & 20 & 5 & 2 & 6.700 & 1.675 \\
3 & 20 & 5 & 2 & 3.047 & 0.761 \\
4 & 20 & 5 & 2 & 1.746 & 0.436 \\
5 & 20 & 5 & 2 & 1.585 & 0.396 \\
\hline 6 & 20 & 5 & 2 & 1.191 & 0.297 \\
\hline
\end{tabular}

FAO/WHO Codex Alimentarius Commission Recommended

* MRL of Diazinon : $0.5 \mathrm{ppm}$

** ADI of Diazinon : $0.002 \mathrm{ppm} / \mathrm{kg}$ body weight

*(MRL Maximum Residue Limit); **(ADI Acceptable Daily Intake)

Residue of Diazinon on or in plants, in animal tissues, or even in the soil are not highly persistent (FAQ-WHO, 1970). From this study, it was revealed that residue of Diazinon could be detected up to 6 DAS. The quantities of residue were above MRL upto 3 DAS and these were $2.228 \mathrm{ppm}, 1.889 \mathrm{ppm}, 1.675 \mathrm{ppm}$, and $0.761 \mathrm{ppm}$ at $0,1,2$ and 3 DAS, respectively. Samples of 4, 5, and 6 DAS contained $0.436 \mathrm{ppm}, 0.396 \mathrm{ppm}$ and $0.297 \mathrm{ppm}$. Diazinon residue, respectively, which are below MRL set by FAQ-WHO (1970). This results more or less agree with the observation of Geigy (1 956-67). He observed the Diazinon residue level after spraying the field dose, were $<0.1 \mathrm{ppm}$ in Cabbage at 7 DAS, $0.4 \mathrm{ppm}$ in Cauliflower at 5 DAS and $<0.1 \mathrm{ppm}$ in Cucumber at 7 DAS. Adnan et al. (1987) found Diazinon residue above MRL upto 8 DAS in sweet pepper grown in green house.

\section{Carbosulfan (Sunsalfan 20 EC)}

The brinjal samples containing Carbosulfan residue were analyzed using the CCMS QP2010 and the chromatograms of the injected extracts of different DAS are shown in Fig. 8- 15.

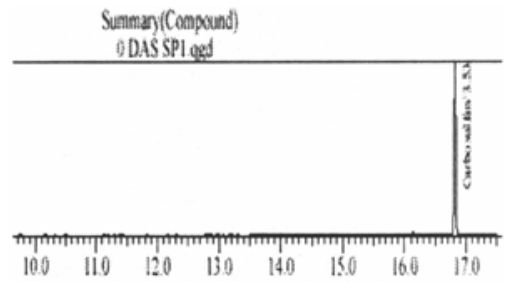

Fig. 8: Chromatogram of Carbosulfan obtained from brinjal extract after o DAS.

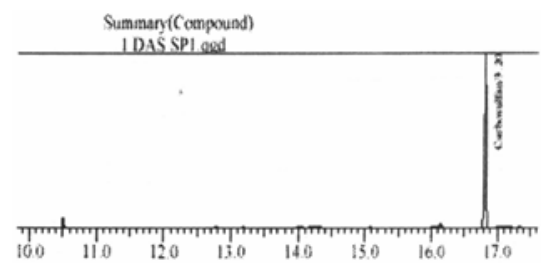

Fig. 9: Chromatograrn of Carbosulfan obtained from brinjal extract after I DAS 


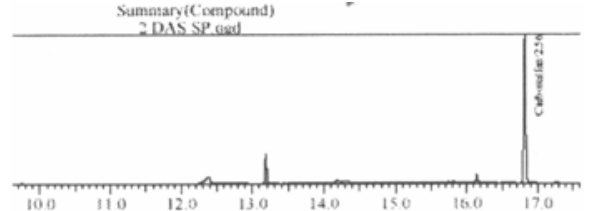

Fig. 10. Chromatogram of Carbosulfan obtained from brinjal extract after 2 DAS.

Summany(Compound)

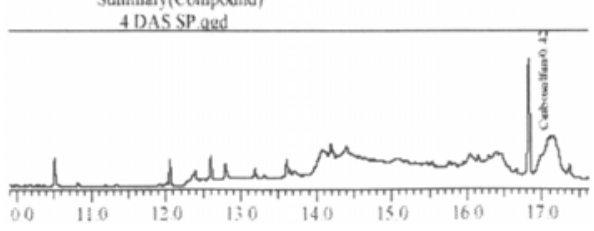

Fig. 12. Chromatogram of Carbosulfan obtained from Brinjal extract after 5 DAS.

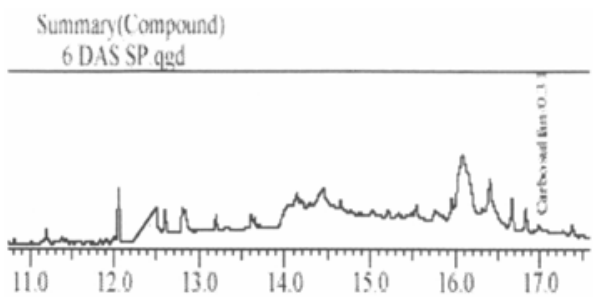

Fig. 14. Chromatogram of Carbosulfan obtained from brinjal extract after 6 DAS.

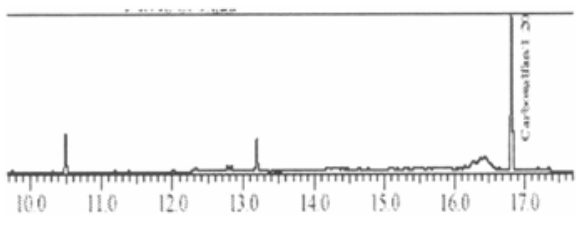

Fig. 11: Chromatogram of Carbosulfan obtained from brinjal extract after 3 DAS.

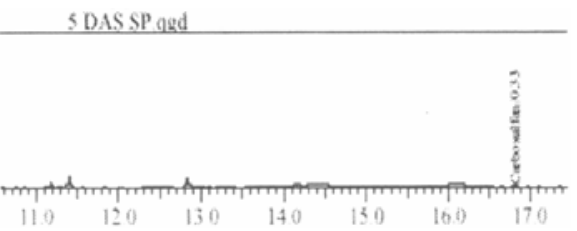

Fig. 12. Chromatogram of Carbosulfan obtained from Brinjal extract after 4 DAS.

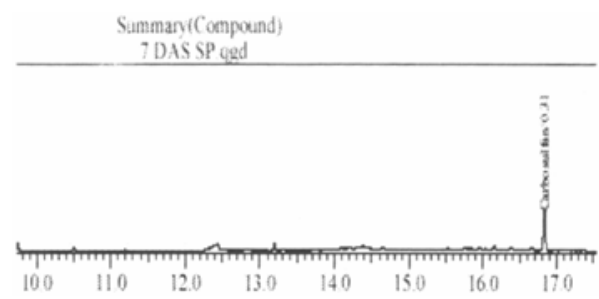

Fig. 15. Chromatogram of Carbosulfan obtained from brinjal extract after 7 DAS

The estimated residue level of Carbosulfan obtained from different DAS are shown in the Table 2.

Table 2. Quantity of residue of Carbosulfan (Sunsulfan 20 EC estimated from brinjal at different days after spray (DAS).

\begin{tabular}{c|c|c|c|c|c}
\hline $\begin{array}{c}\text { Days after } \\
\text { spraying }\end{array}$ & $\begin{array}{c}\text { Sample } \\
\text { wt (g) }\end{array}$ & $\begin{array}{c}\text { Total volume } \\
\text { prepared }(\mathrm{ml})\end{array}$ & $\begin{array}{c}\text { Injected } \\
\text { volume } \\
(\mu \mathrm{l})\end{array}$ & $\begin{array}{c}\text { Concent. } \\
\text { obtained in final } \\
\text { volume }(\mathrm{ppm})\end{array}$ & $\begin{array}{c}\text { Residue of } \\
\text { Sunsulfan left } \\
(\mathrm{mg} / \mathrm{kg})\end{array}$ \\
\hline 0 & 20 & 5 & 2 & 3.529 & 0.882 \\
1 & 20 & 5 & 2 & 3.197 & 0.799 \\
2 & 20 & 5 & 2 & 2.557 & 0.639 \\
3 & 20 & 5 & 2 & 1.195 & 0.299 \\
4 & 20 & 5 & 2 & 0.417 & 0.104 \\
5 & 20 & 5 & 2 & 0.333 & 0.083 \\
6 & 20 & 5 & 2 & 0.311 & 0.078 \\
7 & 20 & 5 & 2 & 0.305 & 0.076 \\
\hline
\end{tabular}

FAQ/WHO Codex Alimentarius Comhmission Recommended

*MRL of Carbosulfan : $0.2 \mathrm{mg} / \mathrm{kg}$ crop

**ADI of Carbosulfan : $0.002 \mathrm{mg} / \mathrm{kg}$ body weight 
Carbosulfan residue was detected in the sample upto 7 DAS (Table 2) and the quantities were over MRL upto 3 DAS. At 0 DAS, the residue in the sample was $0.882 \mathrm{ppm}$, which degrades to $0.799 \mathrm{ppm}$ at 1 DAS. At 2 DAS, the quantity of residue was $0.639 \mathrm{ppm}$ and at the next day, the amount of detected residue decreased to was $0.299 \mathrm{ppm}$. At 4 DAS, it was $0.104 \mathrm{ppm}$, which was below the MRL. And at 5, 6, and 7 DAS, the quantities of residue were $0.083 \mathrm{ppm}, 0.078$, ppm and 0.076 ppm, respectively. From a study by Trevisan et al. (2004), it was revealed that the residue level of Carbosulfan in citrus decreased rapidly and being not found in samples after 7 DAS. Varca et al. (1998) also reported that in rice leaves, Carbosulfan residue lasted till 7 DAS. In another study by Rajeswaran et al. (2004), the residue of Carbosulfan was found below the MRL at the first harvest, while it was sprayed at the recommended dose of $250 \mathrm{~g}$ a.i. ha ${ }^{-1}$.

\section{Quinalphos (Kinalux 25 EC)}

The yard long bean (YLB) samples containing Quinalphos residue also were analyzed using the GC-MS QP2010 and the developed parameters were set. The chromatograms of the injected extracts of YLB at different DAS are shown in Fig. 16-23.
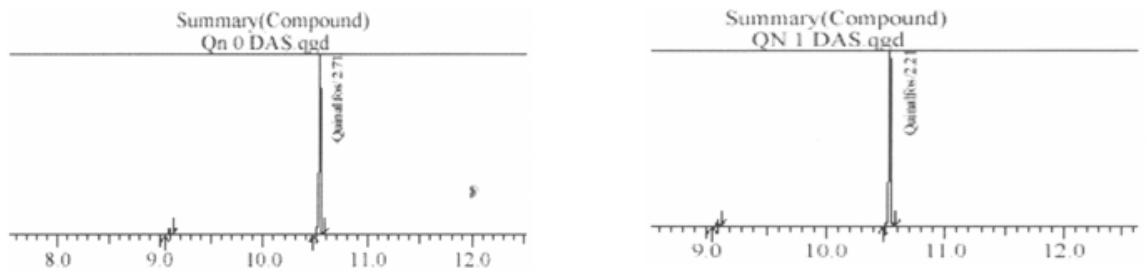

Fig. 16. Chromatogram of Quinaiphos obtained Fig. 17. Chromatogram of Quinaiphos obtained from YLB extract after 0 DAS. from YLB extract after I DAS.
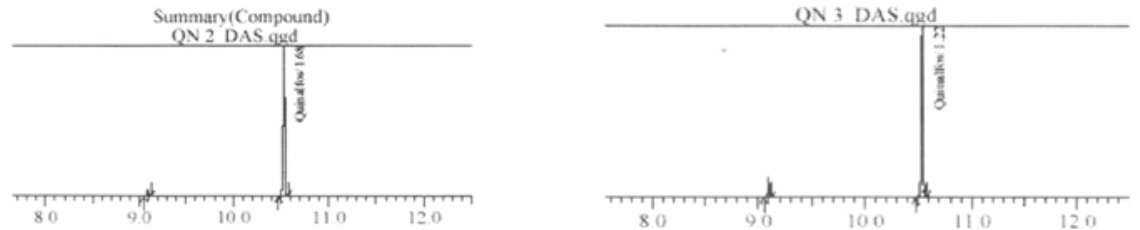

Fig. 18. Chromatogram of Quinaiphos obtained Fig. 19. Chromatogram of Quinaiphos obtained from YLB extract after 2 DAS. from YLB extract after 2 DAS. from YLB extract after 3 DAS.
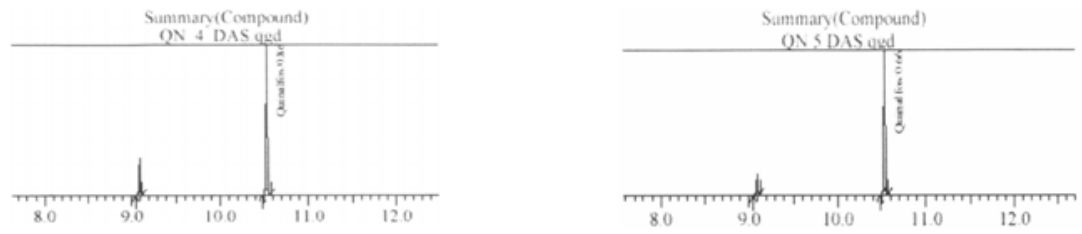

Fig. 20. Chromatogram of Quinaiphos obtained Fig.2 1. Chromatogram of Quinaphos obtained from YLB extract after 4 DAS.

from YLB extract after 5 DAS. 


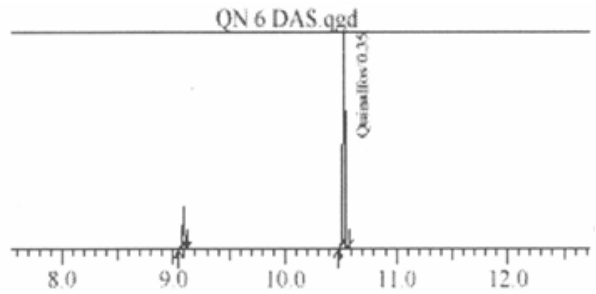

Fig.22. Chromatogram of Quinaiphos obtained from LB extract after 6 DAS.

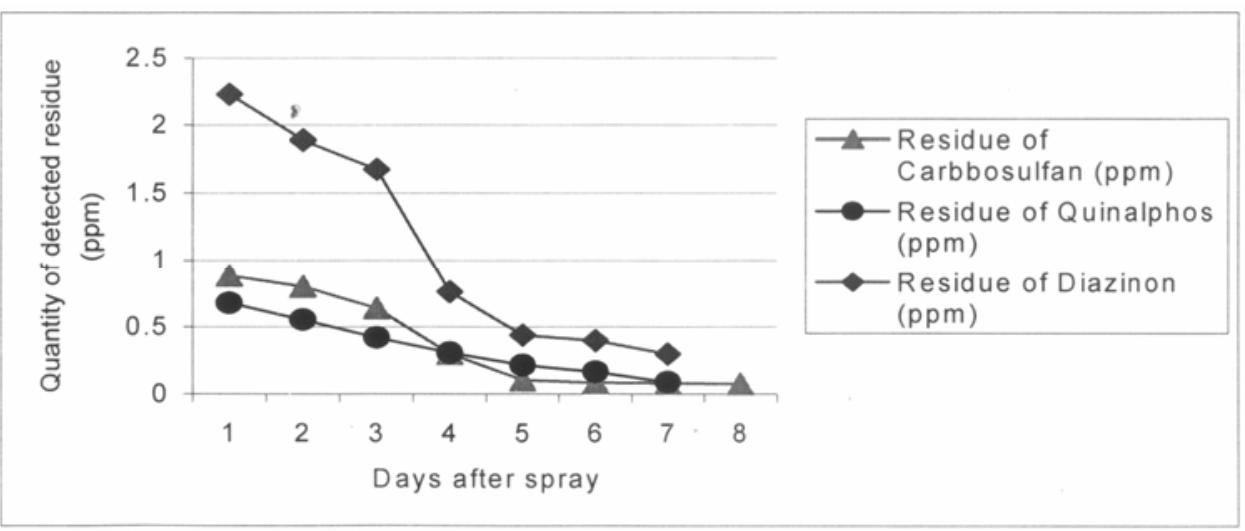

Fig 23. The trend of degradation of detected residue of different insecticide groups over time.

Table 3 shows the analysis results of Quinalphos residue in yard long bean.

Table 3. Quantity of residue of Quinaiphos (Kinalux 25EC) estimated from yard long bean at different Days after Spray (DAS).

\begin{tabular}{l|c|l|l|l|l}
\hline $\begin{array}{c}\text { Days } \\
\text { ffter } \\
\text { spraying }\end{array}$ & $\begin{array}{c}\text { Sample } \\
\text { weight } \\
(\mathrm{g})\end{array}$ & $\begin{array}{c}\text { Total volume } \\
\text { prepared (ml) }\end{array}$ & $\begin{array}{c}\text { Injected } \\
\text { volume } \\
(\mu 1)\end{array}$ & $\begin{array}{c}\text { Concentration } \\
\text { obtained in final } \\
\text { volume }(\mathrm{ppm})\end{array}$ & $\begin{array}{c}\text { Residue of } \\
\text { Kinalux } \\
\text { left }(\mathrm{mg} / \mathrm{kg})\end{array}$ \\
\hline 0 & 20 & 5 & 2 & 2.713 & 0.678 \\
1 & 20 & 5 & 2 & 2.209 & 0.552 \\
2 & 20 & 5 & 2 & 1.679 & 0.419 \\
3 & 20 & 5 & 2 & 1.224 & 0.306 \\
4 & 20 & 5 & 2 & 0.856 & 0.214 \\
5 & 20 & 5 & 2 & 0.657 & 0.164 \\
6 & 20 & 5 & 2 & 0.349 & 0.087 \\
\hline
\end{tabular}

FAQ/WHO Codex Alimentarius Commission Recommended

*MRL of Kinalux $0.2 \mathrm{mg} / \mathrm{kg}$ crop

**ADI of Kinalux $0.002 \mathrm{mg} / \mathrm{kg}$ body weight

*(MRL - Maximum Residue Limit); ** (ADI- Acceptable Daily Intake)

Quinaiphos is a less persistent insecticide and dissipated on the fruits more quickly than Fenvalerate and Carbaryl (Devi and Manjunath, 1985). In the current study, the left over residue of Quinaiphos in the YLB sample had been 
detected upto 6 DAS, of which upto 4 DAS, the quantity of residue were above MRL. At the 0 DAS, the residue was $0.678 \mathrm{ppm}$ and they were $0.552 \mathrm{ppm}, 0.419$ ppm, $0.306 \mathrm{ppm}$, and $0.214 \mathrm{ppm}$ at 1 DAS, 2 DAS, 3 DAS, and 4 DAS, respectively. All these quantities were above MRL. The quantity decreased down to $0.164 \mathrm{ppm}$ at 5 DAS and $0.087 \mathrm{ppm}$ at 6 DAS. But Devi and Manjunath (1985) found the residue of Quinalphos (0.56 ppm) in brinjal above the tolerance level upto 10 DAS. Kumari et al. (2004) found the presence of Quinaiphos residue in farmgate vegetables in Delhi though it was below the MRL.

\section{Trend of degradation}

The trend of degradation of detected residue of Diazinon, Carbosulfan, and Quinalphos in the sample over time is shown in Fig. 23. From the figure, it is observed that the degradation rate of all three groups of insecticide is very slow at first three days and after that Diazinon residue decreased abruptly though it was above MRL. The rate of degradation is very low in case of Carbosulfan, but it was below MRL.

\section{References}

Adnan, I., Al-Samariee, A. M. S. Khloud and A. A.B. Mabrouk. 2006. Residue levels of three organophosphorus insecticides in sweet pepper grown in commercial green houses, Pesticide Science, John Wiley and Sons, Ltd. 22(3):189-194.

Annonymous. 2000. Annual Report. 1999-2000, Entomology Division, Bangladesh Agricultural Research Institute, Joydebpur, Gazipur, bangladesh.

Antle, J. M. and P. L. Pingali. 1994. Pesticides, Productivity, and Farmer Health: A Philippine Case Study. American Journal of Agril. Economics 76: 4 18-430.

Devi. L. S. and C.E. Manjunath. 1985. Current Research, University of Agricultural Sciences, Bangalore 14(4/6):34-35.

FAO and WHO. 1970. Evaluation of some pesticides in food, WHO, FOOD ADD), 71:42.

Geigy Chemical Company. 1956-67. Unpublished data and methods of analysis in pesticide petitions, submitted to the U.S. Food and Drug Administration.

Hossain, M. I., G. Shively and C. Mahmoud. 2000. Pesticide Expenditure in a Rice Vegetable Farming System: Evidence from Low-income Farms in Bangladesh, IPMCRSP Working Paper 00-5.

Hoque, M.E. 2000. Crop diversification in Bangladesh. M.K. Papdemetrioii and F.J. Dent (eds.). Crop diversification in the Asia-Pacific region, Bangkok, Thailand: Food and Agriculture Organization of the United Nations.

Khatoon, J. A., M. S. Islam, N. M. Talukder and M. A. Hossain. 2004. Monitoring the residue level of three selected pesticides in Red Amaranth. J. Biol. Sci. 4(4): 474479. 
Kumari, B., V.K. Madan, Jagdeep Singh and T. S. Kathpal. 2004. Monitoring of pesticidal contamination of Farmgate Vegetables. Journal of Earth and Environmental Science, Springer Netherlands 90 (1-3): 65-71.

Rajeswaran, Merlinkamala, Chandrasekaran, Jayakumar and Kuttalam. 2004. Journal of Food, Agriculture and Environment, WFL, 2(2).

Trevisan, M. J., G. C. Baptista, L. R. P. Trevizan and G.Papa. 2004. Residue of Carbosulfan and its Caebofuran metebolites and 3-hydroxy- carbofuran in oranges, Rev. Bras. Frutic. 26 (2).

Varca, L. M., A. W. Tajeda, I. R. Kennedy,J. H. Skerrit and E. Highly. 1998. Dissipation of pesticide in rice paddy in the Philippines. ACIAR: Proceedings Series, Canberra, 85 (17-19): 140-14 1.

Weinberger, K. and C.A. Genova II. 2005. Vegetable production in Bangladesh: commercialization and rural live! ihood S. Technical Bulletin No 33. Shanh ua, Taiwan: AVRDC-Thc World Vegetable Center. 05-621 (5 1). 